\title{
Pengaruh Stres Kerja dan Komunikasi Terhadap Kinerja Karyawan PT. Sekawan Kontrindo Palembang
}

\author{
Sopian \\ Manajemen, STIE Mulia Darma Pratama Palembang \\ email: akangsopi@gmail.com
}

\begin{abstract}
ABSTRAK
Tujuan dari penelitian ini berdasarkan rumusan masalah yang ada adalah untuk mengetahui apakah stres kerja dan komunikasi memilki pengaruh terhadap kinerja karyawan PT. Sekawan Kontrindo Palembang. Populasi dalam penelitian ini adalah seluruh karyawan 33 karyawan PT. Sekawan Kontrindo Palembang, sedangkan sampel dalam penelitian ini menggunakan sampel jenuh. Jenis data yang digunakan adalah data primer dengan metode pengumpulan data kuesioner. Teknik analisis yang digunakan yaitu analisis kuantitatif. Hasil analisis dalam penelitian ini menunjukkan bahwa diperoleh $F_{\text {hitung }}$ 107,096 > Ftabel 2,922 jadi hipotesis nol ditolak dapat disimpulkan bahwa variabel Stres Kerja $\left(X_{1}\right)$ dan Komunikasi $\left(X_{2}\right)$ secara bersama-sama berpengaruh terhadap Kinerja $(Y)$. Hasil uji parsial (uji t) dapat dijelaskan variabel Stres Kerja $\left(\mathrm{X}_{1}\right)$ berpengaruh signifikan terhadap Kinerja $(\mathrm{Y})$ hasil diperoleh thitung 3,910 > tabel 1,697, jadi hipotesis alternatif diterima dan hipotesis nol ditolak. Variabel Komunikasi $\left(\mathrm{X}_{2}\right)$ berpengaruh signifikan terhadap Kinerja $(\mathrm{Y})$ hasil diperoleh thitung 3,701 > tabel 1,697 , jadi hipotesis alternatif diterima dan hipotesis nol ditolak.
\end{abstract}

Kata Kunci : stres kerja, komunikasi, dan kinerja

A. Latar Belakang

Sumber Daya Manusia (SDM) sangatlah penting guna memperoleh kinerja karyawan seperti yang diharapkan dalam rangka mencapai visi dan misi serta tujuan organisasi. Apabila kinerja karyawan tidak sesuai yang diharapkan, tingkat absensi serta ketidak hadiran karyawan tinggi, dapat dipastikan terdapat suatu masalah yang bersangkutan dengan karyawan dan akan berdampak pada penurunan kinerja perusahaan. Kinerja yang menurun salah satunya dapat disebabkan oleh stres yang dialami karyawan.

$\begin{array}{ccr}\text { Menurut } & \text { Sasono } & (2004: 5) \\ \text { mengungkapkan } & \text { bahwa } & \text { stres }\end{array}$ mempunyai dampak positif dan negatif. Dampak positif stres pada tingkat rendah sampai pada tingkat moderat bersifat fungsional dalam arti berperan sebagai pendorong peningkatan kinerja karyawan. Sedangkan pada dampak negatif stres tingkat yang tinggi adalah penurunan pada kinerja karyawan yang drastis. Stres kerja merupakan aspek yang penting bagi perusahaan terutama keterkaitannya dengan kinerja karyawan. Perusahaan harus memiliki kinerja, kinerja yang baik/tinggi dapat membantu perusahaan memperoleh keuntungan. Sebaliknya, bila kinerja menurun dapat merugikan perusahaan. Oleh karenanya kinerja karyawan perlu memperoleh perhatian antara lain dengan jalan melaksanakan kajian berkaitan dengan variabel stres kerja.

Bahaya stres diakibatkan karena kondisi kelelahan fisik, emosional dan mental yang disebabkan oleh adanya keterlibatan dalam waktu yang lama dengan situasi yang menuntut secara emosional. Proses berlangsung secara bertahap, akumulatif, dan lama kelamaan menjadi semakin memburuk. Dalam jangka pendek, stres yang dibiarkan begitu saja tanpa penanganan yang serius dari pihak perusahaan membuat karyawan menjadi tertekan, tidak termotivasi, dan 
frustasi menyebabkan karyawan bekerja tidak optimal sehingga kinerjanya pun akan terganggu. Dalam jangka panjang, karyawan tidak dapat menahan stres kerja maka ia tidak mampu lagi bekerja diperusahaan. Pada tahap yang semakin parah, stres bisa membuat karyawan menjadi sakit atau bahkan akan mengundurkan diri (turn over). Stres kerja yang dialami oleh karyawan dapat merugikan perusahaan karena tidak imbangnya antara produktivitas dengan biaya yang dikeluarkan untuk membayar gaji, tunjangan, dan fasilitas lainnya. Banyak karyawan yang tidak masuk kerja dengan berbagai alasan, atau pekerjaan tidak selesai pada waktunya entah karena kelambanan ataupun karena banyaknya kesalahan yang berulang. Agar karyawan terhindar dari stres yang merugikan bagi perusahaan, dibutuhkan komunikasi yang baik dalam suatu orgnisasi atau perusahaan.

Stres pekerjaan dapat diartikan sebagai tekanan yang dirasakan karyawan karena tugas-tugas pekerjaan tidak dapat mereka penuhi. Artinya, stres muncul saat karyawan tidak mampu memenuhi apa yang menjadi tuntutan-tuntutan pekerjaan. Selain stres kerja, dalam organisasi pencapaian tujuan dengan segala prosesnya membutuhkan komunikasi yang efektif. Para anggota organisasi mutlak perlu berkomunikasi satu sama lain. Bahwa terjadinya stres kerja adalah dikarenakan adanya ketidakseimbangan antara karakteristik kepribadian karyawan dengan karakteristik aspek-aspek pekerjaannya dan dapat terjadi pada semua kondisi pekerjaan.

Sebagai manusia biasa karyawan PT. Sekawan Kontrindo Palembang tentunya dihadapkan dengan kondisi ini dilematis. Di satu sisi mereka harus bekerja untuk fokus pada visi perusahaan yaitu memberi kepuasan bagi pelanggan sementara disisi lain mereka memiliki kebutuhan dan keinginan yang perlu mendapat perhatian dari perusahaan. Kondisi tentunya akan menimbulkan stres kerja. Sasono (2004:5) mengungkapkan bahwa stres mempunyai dampak positif dan negatif. Dampak positif stres pada tingkat rendah sampai pada tingkat moderat bersifat fungsional dalam arti berperan sebagai pendorong peningkatan kinerja karyawan. Sedangkan pada dampak negatif stres tingkat yang tinggi adalah penurunan pada kinerja karyawan yang drastis. Oleh sebab itu penting bagi perusahaan PT. Sekawan Kontrindo Palembang untuk memenuhi kebutuhan karyawan dan menciptakan kenyamanan kerja sehingga stres kerja dapat dihindari atau diminimalkan. Stres pekerjaan dapat diartikan sebagai tekanan yang dirasakan karyawan karena tugas-tugas pekerjaan tidak dapat mereka penuhi. Artinya, stres muncul saat karyawan tidak mampu memenuhi apa yang menjadi tuntutan-tuntutan pekerjaan.

Komunikasi merupakan bagian integral dari suatu proses manajemen, melalui komunikasi yang efektif kerja sama yang harmonis dapat dikembangkan untuk mencapai tujuan. Seperti yang dikatakan GR Terry (dalam Sopiah, 2008:152) komunikasi menempati urutan teratas mengenai apa saja yang harus dibuat dan dikerjakan untuk menghasilkan kerja efektif, usaha-usaha komunikatif berpengaruh terhadap kinerja karyawan. Sedangkan menurut Widjaja (2008:1) komunikasi adalah hubungan kontak antara manusia baik individu maupun kelompok

Sebagai seorang manajer berperan penting dalam menciptakan suasana yang tertib dan nyaman diantara sesama anggota organisasi, 
seiring dengan perkembangan zaman yang semakin pesat, setiap perusahaan dituntut untuk dapat bersaing dan tetap bertahan agar tujuan yang diinginkan tercapai. Pencapaian tujuan harus didukung dengan komunikasi yang baik dan lancar guna meningkatkan semangat dan kepuasan sehingga kinerja karyawan juga meningkat. Kinerja karyawan adalah hasil kerja yang dicapai seseorang atau kelompok orang yang sesuai dengan wewenang/tanggung jawab masingmasing karyawan selama periode tertentu. Penilaian hendaknya memberikan suatu gambaran akurat mengenai prestasi karyawan. Untuk tujuan ini sistem penilaian harus mempunyai standar dan menggunakan berbagai ukuran yang dapat diandalkan. Adapun faktor-faktor yang dinilai pada penilaian karyawan yaitu hasil kerja diantaranya kualitas, kuantitas pekerjaan dan sifat pribadi, diantaranya orientasi pada pelanggan, kerjasama, kemampuan teknik, akhlak, kedisiplinan, motivasi berprestasi, inisiatif dan pengembangan diri.

Untuk mencapai kinerja seperti yang diinginkan, harus diperhatikan tingkat stres kerja karyawan dan komunikasi yang efektif antara atasan dan bawahan dan sesama karyawan.

\section{B. Rumusan Masalah}

Rumusan masalah dalam penelitian ini yaitu adakah "Pengaruh Stres Kerja dan Komunikasi terhadap Kinerja Karyawan PT. Sekawan Kontrindo Palembang?"

\section{Populasi dan Sampel}

1. Populasi Penelitian

Menurut Arikunto (2010:130) populasi adalah keseluruhan subyek penelitian. Adapun yang menjadi populasi dalam penelitian ini adalah karyawan PT. Sekawan Kontrindo
Palembang yang berjumlah 33 orang karyawan tetap.

2. Sampel Penelitian

Menurut Arikunto (2010:174) sampel adalah sebagian atau wakil populasi penelitian. Selanjutnya menurut Arikunto apabila subjek yang diteliti kurang dari 100, lebih baik diambil semua sehingga penelitiannya merupakan penelitian populasi, sedangkan jika subjek penelitian lebih dari 100, maka diambil 10\% - 15\% atau $20 \% \quad-\quad 25 \%$ tergantung kemampuan penelitian yang dilihat dari segi waktu dan luasnya wilayah penelitian.

Dengan mempertimbangkan kecilnya jumlah populasi, maka jumlah sampel dalam penelitian ini adalah semua populasi yang akan diteliti yaitu berjumlah 33 orang karyawan tetap. Teknik sampel yang digunakan yaitu sampel jenuh. Sampel jenuh adalah teknik penentuan sampel bila semua anggota populasi digunakan sebagai sampel (Sugiyono, 2016:124).

\section{Teknik Pengumpulan Data}

Adapun teknik pengumpulan data dalam penelitian ini adalah sebagai berikut :

1. Sumber Data

Sumber data yang digunakan dalam penelitian ini bersumber dari:

a. Data Primer

Data yang diamati dan dicatat atau diolah untuk pertama kalinya oleh peneliti serta diperoleh langsung dari objek penelitian, yaitu:

1) Wawancara

Wawancara, yaitu data yang diperoleh dengan mengadakan wawancara langsung dengan kepala PT. Sekawan Kontrindo Palembang.

2) Kuisioner 


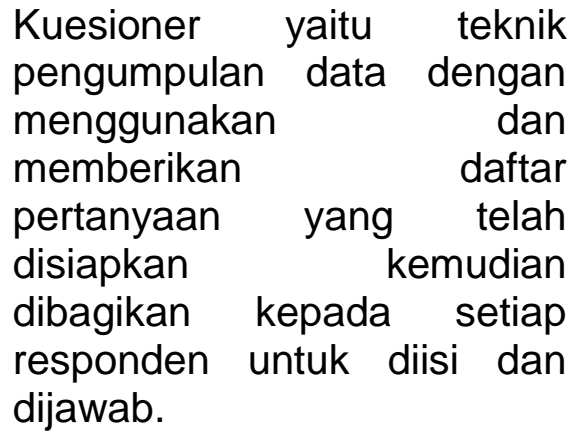

b. Data Sekunder

Data yang diperoleh dari dokumen-dokumen serta arsiparsip yang ada di perusahaan tersebut, dan hasil penelitian kepustakaan dan dari instansi lainnya yang terkait.

\section{E. Kajian Teoritis \\ 1. Pengertian Stres Kerja}

Menurut Soewondo (2003:19) menyatakan bahwa stres kerja adalah suatu kondisi dimana terdapat satu atau beberapa faktor di tempat kerja yang berinteraksi dengan pekerja sehingga mengganggu kondisi fisiologis, dan perilaku. Stres kerja akan muncul bila terdapat kesenjangan antara kemampuan individu dengan tuntutan-tuntutan dari pekerjaannya. Stres merupakan kesenjangan antara kebutuhan individu dengan pemenuhannya dari lingkungan. Dikalangan para pakar sampai saat ini belum terdapat kata sepakat dan kesamaan persepsi tentang batasan stress. Baron dan Greenberd (dalam Mardiana 2001:21), mendefinisikan stres sebagai reaksi-reaksi emosional dan psikologis yang terjadi pada situasi di mana tujuan individu mendapat halangan dan tidak bisa mengatasinya.

Dari uraian di atas dapat disimpulkan bahwa terjadinya stres kerja adalah dikarenakan adanya ketidakseimbangan antara karakteristik kepribadian karyawan dengan karakteristik aspek-aspek pekerjaannya dan dapat terjadi pada semua kondisi pekerjaan.

\section{Pengertian Komunikasi}

Komunikasi adalah hubungan kontak antara manusia baik individu maupun kelompok. Dalam kehidupan sehari-hari disadari atau tidak komunikasi adalah bagian dari kehidupan manusia itu sendiri. Manusia sejak dilahirkan sudah berkomunikasi dengan lingkungannya (Widjaja, 2008:1). Menurut Ruslan (2008:83) komunikasi merupakan alat yang penting dalam fungsi public relations. Publik menaungi dan menghargai suatu kinerja yang baik dalam kegiiatan komunikasi secara efektif dan sekaligus kinerja yang baik tersebut untuk menarik perhatian publik serta tujuan penting yang lainnya dari fungsi public relations. Menurut Suprapto (2011:6) komunikasi adalah suatu proses interaksi yang mempunyai artiantara sesama manusia.

Berdasarkan kutipan-kutipan di atas, komunikasi dapat disimpulkan merupakan kegiatan interaksi yang dilakukan dari satu orang ke orang lain, sehingga akan terjadi persamaan makna dan tercapai satu tujuan.

\section{Pengertian Kinerja Karyawan}

Kinerja pada dasarnya merupakan perilaku nyata yang dihasilkan setiap orang sebagai prestasi kerja yang dihasilkan oleh karyawan sesuai dengan perannya dalam perusahaan. Untuk mendapatkan kinerja yang baik dari seorang karyawan pada sebuah organisasi harus dapat memberikan sarana dan prasarana sebagai penunjang dalam penyelesaian pekerjaan. Istilah kinerja sendiri merupakan tujuan dari kata Job Performance atau Actual Performance (prestasi kerja atau prestasi 


\begin{abstract}
sesungguhnya yang dicapai oleh seseorang).

Kinerja karyawan adalah hasil kerja yang dicapai seseorang atau kelompok orang sesuai dengan wewenang/tanggung jawab masingmasing karyawan selama periode tertentu. Sebuah perusahaan perlu melakukan penilaian kinerja pada karyawannya. Penilaian kinerja memainkan peranan yang sangat penting dalam peningkatan motivasi di tempat kerja. Penilaian hendaknya memberikan suatu gambaran akurat mengenai prestasi kerja

Menurut Simamora (2004:327) kinerja karyawan adalah tingkat dimana para karyawan mencapai persyaratan-persyaratan pekerjaan.
\end{abstract}

a. Penilaian kinerja karyawan

Yang dimaksud dengan sistem penilaian kinerja ialah proses yang mengukur kinerja karyawan.

Ada beberapa faktor yang mempengaruhi penilaian kinerja karyawan adalah :

1. Karakteristik situasi

2. Deskripsi pekerjaan, spesifikasi pekerjaan dan standar kinerja pekerjaan.

3. Tujuan-tujuan penilaian kinerja.

4. Sikap para karyawan dan manajer terhadap evaluasi.

b. Tujuan Penilaian Kinerja

Tujuan diadakannya penilaian kinerja bagi para karyawan dapat kita ketahui dibagi menjadi dua, yaitu :

1. Tujuan evaluasi

Seorang manajer menilai kinerja dari masalalu seorang karyawan dengan menggunakan rating deskriptif untuk menilai kinerja dan dengan data tersebut berguna dalam keputusankeputusan promosi, demosi, terminasi, dan kompensasi.

2. Tujuan pengembangan

Seorang manajer mencoba untuk meningkatkan kinerja seorang karyawan dimasa yang akan datang.

Kusriyanto,

dalam

Mangkunegara

(2005:9),

mendefenisikan "kinerja sebagai perbandingan hasil yang dicapai dengan peran serta tenaga kerja persatuan waktu (lazimnya per jam)".

\section{F. Hasil Penelitian dan Pembahasan}

\section{Uji Validitas}

Uji validitas adalah untuk mengetahui kelayakan butir-butir dalam suatu daftar pernyataan dengan variabel. Uji ini dilakukan untuk mengukur data yang telah di dapat setelah penelitian. Validitas berhubungan dengan ketepatan alat ukur melakukan tugasnya mencapai sasarannya. Data yang diperoleh melalui kuesioner dapat menjawab tujuan penelitian.

Untuk memperoleh hasil yang terarah dengan kriteria sebagai berikut :

- Jika rhitung > rtabel, maka pernyataan dinyatakan valid.

- Jika rhitung < rtabel, maka pernyataan dinyatakan tidak valid.

Adapun hasil dari uji validitas dalam penelitian ini dapat dilihat pada tabel di bawah ini. 
Tabel 1

Hasil Uji Validitas

\begin{tabular}{|c|c|c|c|}
\hline Variabel & Nilai $\mathbf{r}_{\text {hitung }}$ & Nilai $\mathbf{r}_{\text {tabel }}$ & Keterangan \\
\hline Stres Kerja (X1) & & & \\
Item 1 & $.507^{* *}$ & 0,344 & Valid \\
Item 2 & $.543^{* *}$ & 0,344 & Valid \\
Item 3 & $.693^{* *}$ & 0,344 & Valid \\
Item 4 & $.594^{* *}$ & 0,344 & Valid \\
Item 5 & $.445^{* *}$ & 0,344 & Valid \\
Item 6 & $.664^{* *}$ & 0,344 & Valid \\
Item 7 & $.682^{* *}$ & 0,344 & Valid \\
\hline Komunikasi (X2) & & & \\
Item 1 & $.541^{* *}$ & 0,344 & Valid \\
Item 2 & $.534^{* *}$ & 0,344 & Valid \\
Item 3 & $.817^{* *}$ & 0,344 & Valid \\
Item 4 & $.778^{* *}$ & 0,344 & Valid \\
Item 5 & $.778^{* *}$ & 0,344 & Valid \\
Item 6 & $.625^{* *}$ & 0,344 & Valid \\
Item 7 & $.618^{* *}$ & 0,344 & Valid \\
\hline Kinerja (Y) & & & \\
Item 1 & $.661^{* *}$ & 0,344 & Valid \\
Item 2 & $.520^{* *}$ & 0,344 & Valid \\
Item 3 & $.579^{* *}$ & 0,344 & Valid \\
Item 4 & $.684^{* *}$ & 0,344 & Valid \\
Item 5 & $.668^{* *}$ & 0,344 & Valid \\
Item 6 & $.453^{* *}$ & 0,344 & Valid \\
Item 7 & $.649^{* *}$ & 0,344 & Valid \\
Item 8 & $.640^{* *}$ & 0,344 & Valid \\
\hline
\end{tabular}

Sumber : Data primer yang diolah, 2018

Berdasarkan tabel di atas dapat diketahui perbandingan antara nilai rhitung dan rtabel dari masing-masing item. rtabel dicari pada signifikansi 0,05 dengan uji 2 sisi dan jumlah data $(N)=$ 33, maka didapat $r_{\text {tabel }}$ sebesar 0,344. Karena semua item pernyataan pada masing-masing variabel nilai rhitungnya lebih besar dari $r_{\text {tabel }}$ yaitu 0,344 sehingga dapat dikatakan bahwa semua pernyataan instrumen adalah valid.

\section{Uji Reliabilitas}

Uji reliabilitas digunakan untuk menunjukkan konsistensi dari jawaban responden terhadap pernyataan yang terdapat pada kuisiner dimana telah diuji validitasnya. Suatu instrumen yang dipakai dalam variabel dikatakan handal (reliabel) bila memiliki koefisien Cronbach's Alpha lebih dari 0,60 (Priyanto, 2010:98).

Hasil uji reliabilitas pada penelitian ini dapat dilihat pada tabel di bawah ini :

Tabel 2

Hasil Uji Reliabilitas

\begin{tabular}{|c|l|c|c|}
\hline No. & \multicolumn{1}{|c|}{ Variabel } & Cronbach Alpha & Keterangan \\
\hline 1. & Stres Kerja $\left(\mathrm{X}_{1}\right)$ & .691 & Reliabel \\
\hline 2. & Komunikasi $\left(\mathrm{X}_{2}\right)$ & .768 & Reliabel \\
\hline 3. & Kinerja $(\mathrm{Y})$ & .746 & Reliabel \\
\hline
\end{tabular}

Sumber : Data primer yang diolah, 2018 
Berdasarkan hasil uji reliabilitas dapat diketahui bahwa variabel stres kerja $\left(\mathrm{X}_{1}\right)$, komunikasi $\left(\mathrm{X}_{2}\right)$ dan kinerja (Y) memiliki nilai lebih besar dari 0,60. Dari masing-masing variabel stres kerja $\left(X_{1}\right)$, komunikasi $\left(X_{2}\right)$ dan kinerja (Y) dikatakan handal (reliable) untuk digunakan sebagai alat ukur, karena nilai Cronbach Alpha lebih besar dari 0,60 .

\section{Analisis Statistik Deskriptif}

Penyajian deskripsi data disajikan masing-masing variabel-variabel secara berturut-turut dari variabel sebagai berikut :

Tabel 3

\section{Distribusi Frekuensi}

\begin{tabular}{|c|c|c|c|c|}
\hline \multicolumn{5}{|c|}{ Statistics } \\
\hline & & Stres Kerja & Komunikasi & Kinerja \\
\hline \multirow[t]{2}{*}{$\mathrm{N}$} & Valid & 33 & 33 & 33 \\
\hline & Missing & 0 & 0 & 0 \\
\hline \multicolumn{2}{|l|}{ Mean } & 24.52 & 25.82 & 28.30 \\
\hline \multicolumn{2}{|c|}{ Std. Error of Mean } & .597 & .604 & .698 \\
\hline \multicolumn{2}{|l|}{ Median } & $23.67^{\mathrm{a}}$ & $26.00^{\mathrm{a}}$ & $28.00^{\mathrm{a}}$ \\
\hline \multicolumn{2}{|l|}{ Mode } & 22 & 26 & 26 \\
\hline \multicolumn{2}{|c|}{ Std. Deviation } & 3.429 & 3.468 & 4.012 \\
\hline \multicolumn{2}{|l|}{ Variance } & 11.758 & 12.028 & 16.093 \\
\hline \multicolumn{2}{|l|}{ Skewness } & .441 & .244 & .471 \\
\hline \multicolumn{2}{|c|}{ Std. Error of Skewness } & .409 & .409 & .409 \\
\hline \multicolumn{2}{|l|}{ Kurtosis } & -.678 & .397 & -.008 \\
\hline \multicolumn{2}{|c|}{ Std. Error of Kurtosis } & .798 & .798 & .798 \\
\hline \multicolumn{2}{|l|}{ Range } & 13 & 16 & 17 \\
\hline \multicolumn{2}{|l|}{ Minimum } & 19 & 19 & 21 \\
\hline \multicolumn{2}{|l|}{ Maximum } & 32 & 35 & 38 \\
\hline \multicolumn{2}{|l|}{ Sum } & 809 & 852 & 934 \\
\hline \multirow[t]{9}{*}{ Percentiles } & 10 & $20.53^{b}$ & $20.87^{b}$ & $23.40^{\mathrm{b}}$ \\
\hline & 20 & 21.52 & 22.77 & 25.03 \\
\hline & 30 & 22.16 & 24.36 & 25.97 \\
\hline & 40 & 22.76 & 25.34 & 26.91 \\
\hline & 50 & 23.67 & 26.00 & 28.00 \\
\hline & 60 & 25.32 & 26.55 & 28.82 \\
\hline & 70 & 26.64 & 27.20 & 30.05 \\
\hline & 80 & 27.80 & 28.45 & 31.56 \\
\hline & 90 & 29.20 & 30.13 & 34.20 \\
\hline
\end{tabular}

Sumber : Data primer yang diolah, 2018

Untuk mengetahui pengaruh stres kerja dan komunikasi terhadap kinerja berdasarkan data yang dikumpulkan melalui instrumen penelitian maka dapat diikuti deskriptif berikut ini:

\section{a. Variabel Stres Kerja $\left(\mathbf{X}_{1}\right)$}

Hasil pengolahan data sesuai pada tabel distribusi frekuensi tentang stres kerja $\left(X_{1}\right)$ yang diperoleh melalui instrumen sebanyak 7 pernyataan yang diberikan kepada 33 karyawan pada PT. Sekawan Kontrindo Palembang, ternyata hasil menunjukan bahwa diperoleh skor terendah 19 dan skor tertinggi 32 dengan range 13 dari hasil analisis data diperoleh rata-rata 
(mean) 24,52, Mode 22, Median 23,67, dan Standard Deviation 3,429.
Untuk melihat dalam bentuk frekuensi histogram dapat dilihat pada gambar di bawah ini:

\section{Gambar 1 \\ Histogram Skor Responden Variabel Stres Kerja $\left(X_{1}\right)$ Stres Kerja}

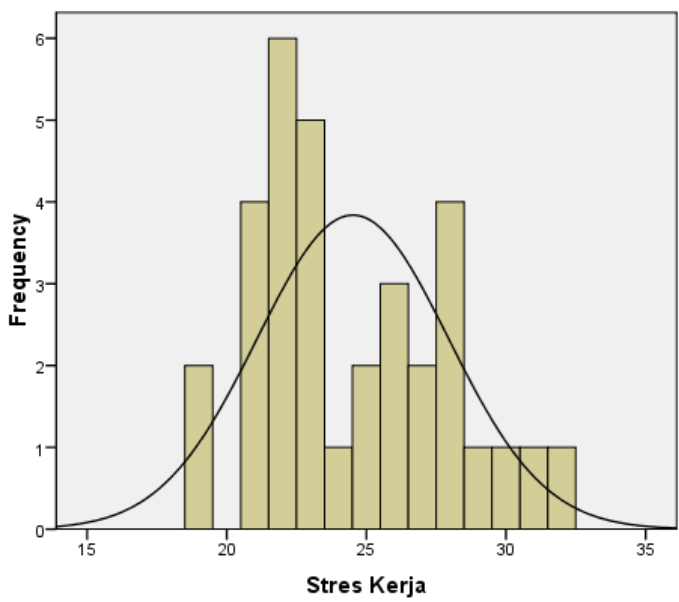
Mean $=24.52$
Std. Dev. $=3.429$
$N=33$

Sumber : Data primeryang diolah, 2018

Dari data di atas menunjukan bahwa rata-rata (mean) dan median dengan mode berbeda. Hal ini menggambarkan distribusi frekuensi variabel stres kerja $\left(\mathrm{X}_{1}\right)$ berdistribusi normal karena sebaran data yang menyebar ke semua daerah kurva normal.

b. Variabel Komunikasi ( $\left.\mathbf{X}_{2}\right)$

Hasil pengolahan data sesuai pada tabel distribusi frekuensi tentang komunikasi $\left(\mathrm{X}_{2}\right)$ yang diperoleh melalui instrumen sebanyak 7 pernyataan yang diberikan kepada 33 karyawan pada PT. Sekawan Kontrindo Palembang, ternyata hasil menunjukan bahwa diperoleh skor terendah 19 dan skor tertinggi 35 dengan range 16 dari hasil analisis data diperoleh rata-rata (mean) 25,82, Mode 26, Median 26,00, dan Standard Deviation 3,468.

Untuk melihat dalam bentuk frekuensi histogram dapat dilihat pada gambar di bawah ini:

\section{Gambar 2}

Histogram Skor Responden Variabel Komunikasi $\left(\mathrm{X}_{2}\right)$ Komunikasi

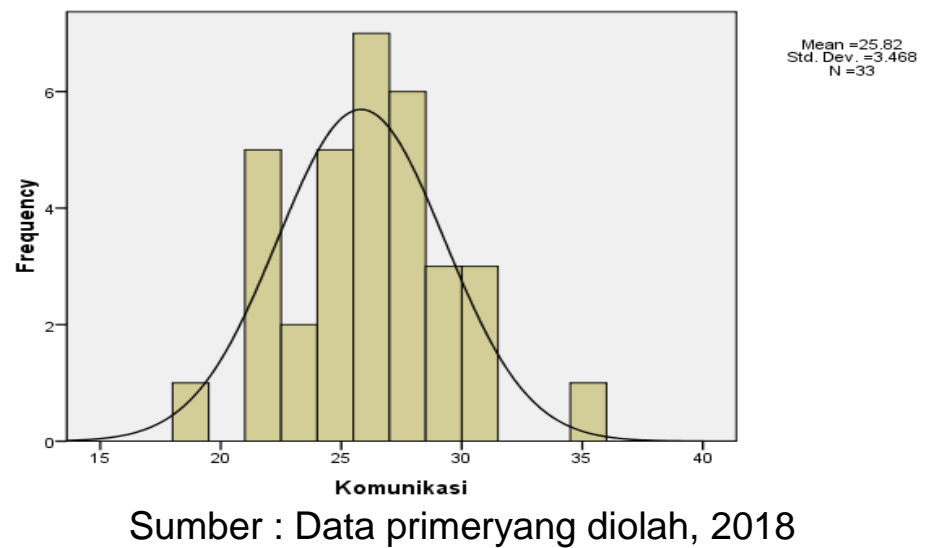


Dari data di atas menunjukan bahwa rata-rata (mean) dan median dengan mode berbeda. Hal ini menggambarkan distribusi frekuensi variabel komunikasi $\left(\mathrm{X}_{2}\right)$ berdistribusi normal karena sebaran data yang menyebar ke semua daerah kurva normal.

\section{c. Variabel Kinerja (Y)}

Hasil pengolahan data sesuai pada tabel distribusi frekuensi tentang kinerja (Y) yang diperoleh melalui instrumen sebanyak 8 pernyataan yang diberikan kepada 33 karyawan pada PT. Sekawan Kontrindo Palembang, ternyata hasil menunjukan bahwa diperoleh skor terendah 21 dan skor tertinggi 38 dengan range 17 dari hasil analisis data diperoleh rata-rata (mean) 28,30, Mode 26, Median 28,00, dan Standard Deviation 4,012.

Untuk melihat dalam bentuk frekuensi histogram dapat dilihat pada gambar di bawah ini:

\section{Gambar 3 \\ Histogram Skor Responden Variabel Kinerja (Y) \\ Kinerja}

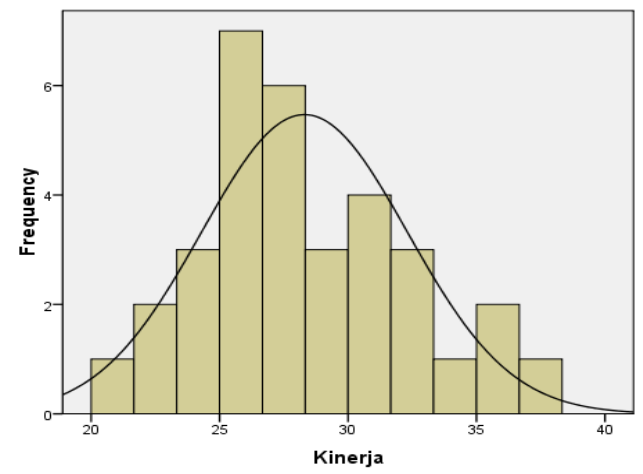

Sumber : Data primer yang diolah, 2018

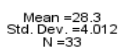

Dari data di atas menunjukan bahwa rata-rata (mean) dan median dengan mode berbeda. Hal ini menggambarkan distribusi frekuensi variabel kinerja $(\mathrm{Y})$ berdistribusi normal karena sebaran data yang menyebar ke semua daerah kurva normal.

\section{Analisis Regresi Linier Berganda}

Analisis regresi linier berganda digunakan dalam penelitian ini dengan tujuan untuk membuktikan hipotesis mengenai pengaruh signifikan dari stres kerja dan komunikasi baik secara simultan maupun parsial terhadap kinerja karyawan pada PT. Sekawan Kontrindo Palembang. Hasil pengolahan data dapat dilihat pada tabel berikut ini :

Tabel 4

Hasil Analisis Regresi Linier Berganda

\begin{tabular}{|c|c|c|c|}
\hline \multicolumn{4}{|c|}{ Coefficients $^{a}$} \\
\hline \multirow{2}{*}{\multicolumn{2}{|c|}{ Model }} & \multicolumn{2}{|c|}{ Unstandardized Coefficients } \\
\hline & & B & Std. Error \\
\hline \multirow[t]{3}{*}{1} & (Constant) & -.072 & 1.962 \\
\hline & Stres Kerja & .583 & .149 \\
\hline & Komunikasi & .546 & .147 \\
\hline
\end{tabular}

a. Dependent Variable: Kinerja

Sumber : Data primer yang diolah, 2018 
Dari hasil tersebut berdasarkan bentuk standardized coefficients beta maka diperoleh persamaan regresi sebagai berikut :

$$
\begin{aligned}
& Y=a+b_{1} X_{1}+b_{2} X_{2}+e \\
& Y=-0,072+0,583 X_{1}+0,546 X_{2}
\end{aligned}
$$$$
+e
$$

$$
\begin{array}{ll}
\text { Keterangan : } \\
\mathrm{Y} & : \text { Kinerja } \\
\mathrm{a} & : \text { Nilai konstanta } \\
\mathrm{b}_{1}, \mathrm{~b}_{2} & : \text { Koefisien Regresi } \\
\mathrm{X}_{1} & : \text { Stres Kerja } \\
\mathrm{X}_{2} & : \text { Komunikasi } \\
\mathrm{e} & : \text { Standar Error }
\end{array}
$$

Persamaan regresi linier berganda di atas dapat dijelaskan sebagai berikut :

a. Konstanta sebesar -0,072; artinya jika Stres Kerja $\left(\mathrm{X}_{1}\right)$ dan Komunikasi $\left(X_{2}\right)$ nilainya adalah 0 , maka Kinerja (Y) nilainya $-0,072$.

b. Koefisien regresi variabel Stres Kerja $\left(X_{1}\right)$ dengan nilai 0,583 ; artinya jika Stres Kerja $\left(\mathrm{X}_{1}\right)$ mengalami kenaikan $1 \%$, maka Kinerja ( $\mathrm{Y}$ ) akan mengalami peningkatan sebesar 0,583 dengan asumsi variabel independen lain nilainya tetap. Koefisien bernilai positif artinya terjadi hubungan positif antara Stres Kerja $\left(\mathrm{X}_{1}\right)$ dengan Kinerja $(Y)$. Semakin naik
Stres Kerja $\left(X_{1}\right)$, maka semakin meningkat Kinerja $(\mathrm{Y})$.

c. Koefisien regresi variabel Komunikasi $\left(\mathrm{X}_{2}\right)$ dengan nilai 0,546 ; artinya jika Komunikasi $\left(\mathrm{X}_{2}\right)$ mengalami kenaikan $1 \%$, maka Kinerja (Y) akan mengalami peningkatan sebesar 0,546 dengan asumsi variabel independen lain nilainya tetap. Koefisien bernilai positif artinya terjadi hubungan positif antara Komunikasi $\left(\mathrm{X}_{2}\right)$ dengan Kinerja ( $\mathrm{Y}$ ). Semakin naik Komunikasi $\left(X_{2}\right)$, maka semakin meningkat Kinerja $(\mathrm{Y})$.

\section{Uji Simultan (Uji F)}

Uji $F$ dilakukan untuk melihat secara bersama-sama apakah ada pengaruh positif dan signifikan dari variabel bebas $(X)$ terhadap variabel terikat (Y). Metode yang digunakan uji $F$ terhadap signifikan model regresi yang menunjukkan mampu tidaknya model atau persamaan yang terbentuk dalam memprediksi nilai variabel terikat dengan tepat.

Adapun hasil dari uji $F$ pada penelitian ini dapat dilihat pada tabel di bawah ini:

\section{Tabel 5 \\ Hasil Uji Simultan (Uji F)}

ANOVA $^{b}$

\begin{tabular}{|ll|r|r|r|r|r|}
\hline Model & & Sum of Squares & Df & Mean Square & F & Sig. \\
\hline 1 & Regression & 451.704 & 2 & 225.852 & 107.096 & $.000^{\mathrm{a}}$ \\
& Residual & 63.266 & 30 & 2.109 & & \\
& Total & 514.970 & 32 & & & \\
\hline
\end{tabular}

a. Predictors: (Constant), Komunikasi, Stres Kerja

b. Dependent Variable: Kinerja

Sumber : Data primer yang diolah, 2018

Kriteria uji yang digunakan adalah :

Ho diterima dan Ha ditolak jika $F_{\text {hitung }}<$ Ftabel

Ha diterima dan Ho ditolak jika Fhitung > $F_{\text {tabel }}$
Berdasarkan hasil uji $F$ pada tabel diperoleh $F_{\text {hitung }}$ sebesar 107,096 dengan tingkat nilai signifikansi sebesar 0,000. Dengan tingkat kesalahan 0,05 dengan $\mathrm{df}_{1}$ (jumlah 
variabel 1) atau 3-1=2, dan $\mathrm{df}_{2}(\mathrm{n}-\mathrm{k}-1)$ atau 33-2-1 = 30 (n adalah jumlah kasus dan $\mathrm{k}$ adalah jumlah variabel independen), hasil diperoleh untuk $F_{\text {tabel }}$ sebesar 2,922. F Fitung $>F_{\text {tabel }}$ $(107,096>2,922)$ jadi hipotesis nol ditolak dapat disimpulkan bahwa variabel Stres Kerja $\left(X_{1}\right)$ dan Komunikasi $\left(\mathrm{X}_{2}\right)$ secara bersama-sama berpengaruh terhadap Kinerja (Y).

\section{Uji Parsial (Uji t)}

Uji ini digunakan untuk mengetahui apakah dalam model regresi variabel bebas variabel Stres Kerja $\left(X_{1}\right)$ dan Komunikasi $\left(X_{2}\right)$ secara parsial mempunyai pengaruh yang signifikan terhadap variabel terikat Kinerja (Y).

Adapun hasil dari uji $t$ pada penelitian ini dapat dilihat pada tabel di bawah ini:

\section{Tabel 6}

\section{Hasil Uji Parsial (Uji t)}

\begin{tabular}{|c|c|c|c|c|c|c|}
\hline \multicolumn{7}{|c|}{ Coefficients $^{a}$} \\
\hline \multirow{2}{*}{\multicolumn{2}{|c|}{ Model }} & \multicolumn{2}{|c|}{ Unstandardized Coefficients } & $\begin{array}{c}\text { Standardized } \\
\text { Coefficients }\end{array}$ & \multirow[b]{2}{*}{$\mathrm{T}$} & \multirow[b]{2}{*}{ Sig. } \\
\hline & & B & Std. Error & Beta & & \\
\hline \multirow[t]{3}{*}{1} & (Constant) & -.072 & 1.962 & & -.037 & .971 \\
\hline & Stres Kerja & .583 & .149 & .498 & 3.910 & .000 \\
\hline & Komunikasi & .546 & .147 & .472 & 3.701 & .001 \\
\hline
\end{tabular}

a. Dependent Variable: Kinerja

Sumber : Data primer yang diolah, 2018

Kriteria pengambilan keputusan :

Ho diterima dan Ha ditolak jika thitung < ttabel

Ha diterima dan Ho ditolak jika thitung $>$ ttabel

Berdasarkan tabel hasil uji parsial (Uji t) di atas dapat dijelaskan bahwa :

1. Variabel Stres Kerja $\left(X_{1}\right)$

Hasil pengujian diperoleh thitung sebesar 3,910 dengan nilai signifikan sebesar 0,000. Dengan tingkat kesalahan 0,05 dengan $\mathrm{df}_{1}$ (jumlah variabel 1) atau 3-1=2, dan $\mathrm{df}_{2}(\mathrm{n}-\mathrm{k}-1)$ atau 33-2-1 = 30 (n adalah jumlah kasus dan $\mathrm{k}$ adalah jumlah variabel independen) hasil diperoleh untuk tabel sebesar 1,697, jadi nilai thitung $>$ tabel $(3,910>$ 1,697), jadi hipotesis alternatif diterima dan hipotesis nol ditolak bahwa Stres Kerja $\left(\mathrm{X}_{1}\right)$ berpengaruh signifikan terhadap Kinerja (Y).

2. Variabel Komunikasi $\left(\mathrm{X}_{2}\right)$
Hasil pengujian diperoleh thitung sebesar 3,701 dengan nilai signifikan sebesar 0,001. Dengan tingkat kesalahan 0,05 dengan $\mathrm{df}_{1}$ (jumlah variabel 1) atau 3-1=2, dan $\mathrm{df}_{2}(\mathrm{n}-\mathrm{k}-1)$ atau $33-2-1=30(\mathrm{n}$ adalah jumlah kasus dan $\mathrm{k}$ adalah jumlah variabel independen) hasil diperoleh untuk tabel sebesar 1,697, jadi nilai thitung $>$ tabel $(3,701>$ $1,697)$, jadi hipotesis alternatif diterima dan hipotesis nol ditolak bahwa Komunikasi (X) berpengaruh namun tidak signifikan terhadap Kinerja (Y).

\section{Koefisien Determinasi $\left(\mathbf{R}^{2}\right)$}

Koefisien determinasi ini digunakan untuk mengetahui seberapa besar pengaruh variabel-variabel bebas memiliki pengaruh terhadap variabel terikat. Nilai koefesien determinasi untuk variabel bebas lebih dari dua digunakan Adjusted $R$ Square sebagai berikut : 
Tabel 7

Koefisien Determinasi $\left(\mathbf{R}^{2}\right)$

\begin{tabular}{|c|c|c|c|c|}
\hline \multicolumn{5}{|c|}{ Model Summary } \\
\hline Model & $\mathrm{R}$ & R Square & Adjusted R Square & $\begin{array}{l}\text { Std. Error of the } \\
\text { Estimate }\end{array}$ \\
\hline 1 & $.937^{\mathrm{a}}$ & .877 & .869 & 1.452 \\
\hline
\end{tabular}

a. Predictors: (Constant), Komunikasi, Stres Kerja

Sumber : Data primer yang diolah, 2018

Koefisien determinasi $R^{2}$ yang diperoleh adalah $0,877(87,7 \%)$ berarti bahwa variabel Stres Kerja $\left(X_{1}\right)$, Komunikasi $\left(X_{2}\right)$ menjelaskan Kinerja (Y) sebesar $87,7 \%$ sedangkan sisanya $12,3 \% \quad(100 \%-87,7 \%) \quad$ dapat dijelaskan oleh variabel lain seperti harga, kualitas produk, distribusi yang tidak diteliti dalam penelitian ini yang dilihat pada Adjusted $R$ Square.

\section{G. Kesimpulan dan Saran}

1. Kesimpulan

Berdasarkan analisa hasil penelitian yang telah dilakukan untuk mengetahui pengaruh stres kerja dan komunikasi terhadap kinerja karyawan PT. Sekawan Kontrindo Palembang dapat ditarik kesimpulan sebagai berikut :

a. Variabel Stres Kerja $\left(X_{1}\right)$ dan Komunikasi $\left(X_{2}\right)$ secara bersamasama berpengaruh terhadap Kinerja (Y) nilai $F_{\text {hitung }}>F_{\text {tabel }}(107,096>$ 2,922) jadi hipotesis nol ditolak.

b. Variabel Stres Kerja $\left(X_{1}\right)$ berpengaruh signifikan terhadap Kinerja $(\mathrm{Y})$ nilai thitung $>$ tabel $(3,910>$ 1,697), jadi hipotesis alternatif diterima dan hipotesis nol ditolak. Kemudian variabel Komunikasi $\left(\mathrm{X}_{2}\right)$ berpengaruh signifikan terhadap Kinerja $(\mathrm{Y})$ nilai thitung $>$ tabel $(3,701>$ 1,697), jadi hipotesis alternatif diterima dan hipotesis nol ditolak.

\section{Saran}

Berdasarkan kesimpulan yang diperoleh dalam penelitian ini, maka diajukan saran-saran dari hasil penelitian sebagai berikut:

a. Disarankan kepada pimpinan PT. Sekawan Kontrindo Palembang agar dapat memperhatikan lagi faktor-faktor yang mempengaruhi kinerja karyawan, hal ini dimaksudkan untuk dapat meningkatkan kinerja karyawan pada PT. Sekawan Kontrindo Palembang. Agar dari segi stres kerja dan komunikasi dengan melakukan riset keinginan dari karyawan dan melakukan penelitian yang lebih akurat lagi.

b. Bagi peneliti selanjutnya harus melakukan penelitian kinerja lebih lanjut, karena masih ada variabelvariabel dan faktor-faktor lain yang belum dapat dijelaskan dalam penelitian ini.

c. Untuk memperkuat hasil penelitian serupa dianjurkan menambah sampel dan menjelaskan proses pengisian kuesioner dan mendampingi responden ketika mengisi kuesioner tersebut.

\section{DAFTAR PUSTAKA}

Arikunto, Suharsimi. 2010. Prosedur Penelitian Suatu Pendekatan Praktek. Jakarta: Rineka Cipta.

Mangkunegara, Anwar Prabu. 2004. Manajemen Sumber Daya Manusia Perusahaan. Bandung: PT. Remaja Rosdakarya. 
Mardiana, Tri dan Muafi. 2001. Studi Empiris Stressor terhadap Kinerja. Jurnal Siasat Bisnis (JSB). Vol.II. No. 6.

Priyatno, Duwi. 2010. Paham Analisa Statistik Data Dengan SPSS. Yogyakarta: Penerbit Medicom.

Ruslan, Rosady. 2008. Manajemen Public Relatoins \& Media Komunikasi. Jakarta: PT Rajagrafindo Persada.

Sasono, Eko. 2004. Mengelola Stres Kerja. Jurnal Fokus Ekonomi. Vol III. No.2

Simamora, Henry. 2004. Manajemen Sumber Daya Manusia, Edisi Ketiga. Yogyakarta: STIE YKPN.
Soewondo, Soesmalijah. 2003. Manajemen Sumber Daya Manusia. Bandung: Alfabeta.

Sopiah. 2008. Perilaku Organisasional. Yogyakarta: Penerbit Andi.

Sugiyono. 2016. Metode Penelitian Bisnis. Bandung: Penerbit Alfabeta.

Suprapto, Tommy. 2011. Pengantar Teori \& Manajemen Komunikasi. Jakarta: PT. Buku Kita.

Widjaja, H.A.W. 2008. Ilmu Komunikasi Pengantar Studi. Rineka Cipta. Jakarta. 